\title{
Effect of Processing Techniques on the Physical and Nutritional Properties of Extruded Product Using Multicereal Composite Mix
}

\author{
Vasantha Kumari. $\mathrm{P}^{1}$, Narayanasamy Sangeetha ${ }^{2}$ \\ ${ }^{I}$ (Research Scholar, Department of Food Science and Technology, Pondicherry University, India) \\ 2 (Assistant Professor, Department of Food Science and Technology, Pondicherry University, India)
}

\begin{abstract}
The Cereals of today are more nutritious and healthful than ever before. Cereals processing is one of the oldest and the most essential part of all food technologies. Besides, it forms a large and indispensable component of the food production chain. The cereals processing industry is as diverse as its range of products. Drying and dewatering plays an important role in food manufacturing and food processing activities worldwide often one of the last operations in the food processing. In this study Pasta formulation was substituted with multi cereal composite mix at three different levels of 50,70 and $90 \%(w / w)$ to enhance the nutritional profile. All the samples were evaluated for physical properties namely bulk density, swelling power, water holding capacity, foam capacity and foam stability, amino acid profile, morphological properties and nutritional properties i.e., protein, ash, crude fiber, fat and carbohydrate and calorific value. Extrusion cooking was carried out using a single screw extruder at 400rpm in different ratios and put forth for the sensory evaluation, colour and cooking qualities.The findings of the study revealed that multi cereal substitute with $50 \%$ showed better result in terms nutrition and physical properties $(P<0.05)$ which would be further utilized in development of therapeutic products.
\end{abstract}

Keywords: Cereals, Dehydration, Processing, Extrusion and Pasta

\section{INTRODUCTION}

Pasta products like macaroni, spaghetti, vermicelli and noodles are largely consumed by the people across the continents. These are traditionally manufactured from refined wheat semolina which is known as the best raw material suitable for pasta production. Pasta is a popular food because of its sensory appeal, versatility, low cost, ease of preparation, excellent dried storage stability and strong nutritional image. Pasta has a complex multi component system consisting of bio macromolecules such as proteins, carbohydrates and lipids [1]. Pasta products have been studied quite extensively that aimed at nutritious pasta which can come out of the image of wheat- based products across the diverse population [2] .The principal reason for exploring several ingredients chiefly originates and emerges from the health- conscious consumers who want to have a product rich in protein, healthful lipids and affords several health benefits. In addition, the consumption of pasta has been increasing among consumers due to rapid urbanization and globalization. Nutritionists consider pasta to be highly digestible, providing significant quantities of complex carbohydrates, low sodium and total fat [3]. However, it is low in dietary fibers, minerals and essential fatty acids according to researchers [4]. It is thus imperative that pasta products need to cater to the nutritional requirements in order to provide the consumers with sufficient nutritional necessity essential to the body. With regard to the traditional pasta, basic ingredients used are wheat flour and water, which may not be adequate to meet the nutrient requirements. One of the solutions to this problem is the incorporation (either as addition or replacement of wheat protein) of ingredients rich in proteins or healthful lipids into pasta formulations. Pasta products can be fortified with protein sources such as fish protein concentrates, soy flour, soy isolates, milk and milk products, cottonseed meal, egg albumin, whey proteins and yeast protein concentrates [5]. In continuation, the current study explores the possibility of multi cereal as a source of essential nutrients and minerals that are requisite for normal growth and development of body. The objective of the present study mainly concentrates on the substitute part of refine flour with multi cereal and its effect on the nutritional properties along with colour and texture.

\subsection{Raw Materials}

\section{Materials And Methods}

The whole cereals with immense nutritional potentiality were selected for the formulation of the multi cereal composite mix and pasta. The raw materials selected for the formulation of multi cereal composite mix were kodo millet, foxtail millet, finger millet, sorghum, oats, maize, barley, wheat and bajra. 


\subsection{Composite Mix Preparation}

The good quality mature ingredients were procured from the supermarket in a bulk quantity and stored in plastic containers, which ensures the uniformity in the ingredients throughout the processing and preparations of multi cereal composite mix and the product. Processing method such as soaking, sprouting, dehydration and milling was carried out for the formulation of multi cereal composite mix. The processed (soaking and sprouting) ingredients were subjected to hot air oven drying. The dehydrated multi cereals were milled to fine powder. The acquired mix was stored in suitable packaging material. Process involved in the preparation of multi cereal composite mix is given in Figure 2.

\subsection{Formulation of Extruded Product - Pasta}

Extrusion is a process used to create objects of a fixed cross-sectional profile. A material is pushed or drawn through a die of the desired cross-section. The two main advantages of this process over other manufacturing processes are its ability to create very complex cross-sections and work materials that are brittle, because the material only encounters compressive and shear stresses. It also forms finished parts with an excellent surface finish according to researchers [6]. Maida and multi cereal composite mix blends were prepared through replacement method, in the ratios (maida/mcm; w/w) of 50:50; 70:30; 90:10 and 100\% (control). Pasta dough (200 g) was prepared and mixed for 20 minutes in a Hobart mixer (model N-50, Ontario, Canada) at 59 RPM. The experiments were carried out in cold extrusion with a single screw extruder (La Monferrinasrl Model dolly) at a pressure of 400 RPM. The speed of the revolving sharp blade cutter in front of the die was adjusted so that the length of the pasta finished at $1.5 \mathrm{~cm}$ and the thickness of $1 \mathrm{~mm}$ for each sample. The process involved in the formulation of multi cereal pasta is given in Figure 3 and the formulated pasta is given in figure1.

\subsection{Quality Characteristics of Composite Mix and Pasta \\ 2.4.1 Physical Parameter}

The physical parameters analyzed for the flour are swelling power (g/g) [7] (Leach et al, 1959), water holding capacity (\%) [8] (Beuchat, 1977), bulk density $\left(\mathrm{g} / \mathrm{cm}^{3)}\right.$ [9] (Okka and Potter, 1979), foam stability and foam capacity (\%) [10] (Narayana and Narasinga Rao, 1982) and moisture content (\%) [11] (AOAC).

\subsubsection{Amino Acid Composition:}

The multi cereal composite mix and maida were evaluated for the amino acid composition using HPLC (lachrome hitachi.). The samples were hydrolyzed at $110{ }^{\circ} \mathrm{C}$ with $6 \mathrm{M} \mathrm{HCl}$. Separations were attained with a 4.6 $\mathrm{mm} \times 150 \mathrm{~mm}$ (cat no. den-5c18-15046) using a binary gradient system with $25 \mathrm{~mm}$ potassium phosphate, ph 3.3 and acetonitrile. The column was maintained at ambient $23^{\circ} \mathrm{c}$ and detected at $254 \mathrm{~nm}$ samples, 5 micro litre of amino acids standards mixture was run as standard reference. Amino acid composition was expressed as grams of amino acid per $100 \mathrm{~g}$ of flour.

\subsubsection{Morphology of Granules}

The morphology of multi cereal composite mix and maida granules was evaluated by scanning electron microscope (SEM) (QUANTA FEG 250 ESEM). Samples were mounted on circular aluminium stubs with double-sided sticky tape. The starch granules were evenly distributed on the surface of the tape. The samples were then coated with $12 \mathrm{~nm}$ gold, examined and photographed at an accelerating voltage of $5 \mathrm{kv}$ with a magnification of $\times 1000$ and $\times 5000$.

\subsubsection{Cooking Qualities}

Cooking Time. Cooking time for pasta was estimated according to [12] AACC methods 66-50 (AACC 2005). The cooking time for pasta was determined by adding a $25 \mathrm{~g}$ portion of the sample into a beaked of $250 \mathrm{ml}$ boiling water. A stopwatch was used and the pieces of pasta were stirred to separate while maintaining a rolling boil. The cooking water was maintained to at least $90 \%$ of its original volume. A piece of pasta was removed from the cooking water at 30-s interval and squeezed between two pieces of clear plastic. The time when the white centre of the sample just disappeared was designated as "cooking time". Cooking time was carried out in triplicate and the mean values were reported.

\section{Cooked Weight.}

The pasta samples were cooked and drained. Cooked weight was determined by weighing the drained pasta. The average means of triplicates were reported in grams. 


\section{Cooking loss and Water Absorption}

Cooking loss was determined according to the Bureau of Indian Standards (BSI 1976). A $20 \mathrm{ml}$ of gruel was pipetted out into a pre weighed petri dish stirring well to give an even distribution of the solid content. It was evaporated to dryness on a water bath. The petri dishes were transferred to a hot air oven maintained at $105 \pm 2^{\circ} \mathrm{C}$ and dried to constant mass. It was then cooled to room temperature in a desiccators and the final weight was noted. Water absorption was calculated according to the increase in weight and expressed as \% of the sample weight before cooking. The average means of triplicates were reported in percentage.

\subsubsection{Chemical Analysis}

The developed composite flour and the pasta was analyzed for Energy by Parr Oxygen Bom Caloimeter Method, Protein by micro Kjeldhal procedure, crude fat using soxhlet extraction, Carbohydrate by anthrone method, iron by calorimetric method, calciun by calorimetric method and vitamin $\mathrm{C}$ by 2,6dichlorophenolendophenol. All the analyses were carried out in triplicate using standard procedures of [11] (AOAC,2000).

\subsubsection{Sensory Evaluation}

Sensory evaluation was conducted by the method suggested by Bhat and Sharma [13], 1989. Samples were presented to a panel of 20 semi trained judges selected from the Department of Food Science and Technology, Pondicherry University. Organoleptic cheracteristcs of cooked noodles were assessed by descripitive sensory profile on color, roughness, firmness, stickiness and starchy mouth coating using the 9 point headonic scale ranging from 1 indicating dislike verymuch to 9 indicating like very much with neutral category of 5 indicating neither like nor dislike.

\subsubsection{Colour Measurement.}

The bright yellow color of pasta products, rather than cooking behavior and taste, is reported to be one of the most important considerations in assessing wheat quality for pasta products (madhumitha and prabhasankar 2011). The vale surface color (L, a and b) of raw pasta in terms of lightness (L), color (+a:reda:green; +b: yellow;-b: blue) and DE were measured using hunter lab color measuring system ( color measuring labscan XE system, hunter associates laboratory inc., reston, VA). A standard white tile of barium sulfate $(100 \%$ reflectance) was used as a perfectly white object for calibration of the instrument with the illuminant. Pasta samples were placed in the sample holder and the reflectance was autorecorded for the wavelength ranging from 360 to $800 \mathrm{~nm}$.

\subsubsection{Moisture}

The active part of moisture content is water activity which provide better information than the total moisture content with respect to the micro-biological, chemical and enzymatic stability of perishable foods. The initial and final moisture content of the product was measured using moisture meter. The initial moisture was calculated as soon as the product comes out of the extruder. The final moisture was evaluated after drying the product in the hot air oven at 60 for $2 \mathrm{hrs}$.

\subsection{Processing Of The Data}

Statistical analysis was carried out using statistical tool SPSS. The data was subjected to ANOVA. The significance of mean differences was determined by Least Significant Difference (LSD).

\subsection{Physical Properties of Multi Cereal Composite Mix}

\section{Results And Discussion}

The results of physical properties of multi cereal composite mix are given in table1. Swelling power has been directly associated with the presence of starch which indicates the ability to absorb water and increase in size [15]. The swelling power of the control was found to be 3.46 and it ranges between 3.13 and 3.28 for the multi cereal composite mix. The decrease observed in swelling power of multi cereal composite mix due to the decrease in starch content during germination process. Extrusion process involves starch gelatinization and responsible for product characteristics of extruded product [16]. Hence the flour has higher swelling power more appropriate for the extrusion process.

Imbibitions of water are the significant functional traits in foods such as dough, sausages and custards. Moreover, water holding capacity is useful in structure interaction in food especially, in flavor retention, improvement of palatability and extension of shelf life particularly in bakery products [17]. Water holding capacity of the formulated multi cereal composite mix50:50, 70:30, 90:10 was found to be 1.78, 1.8 and 1.13 respectively. Water holding capacity is important in the development of ready to eat foods and high absorption capacity may assure product cohesiveness [18]. Extrusion process involves the phase transition of various macro 
molecules and the water content enhances this phase transition process contributing the final product characteristics [19].

The bulk density of a good material is important in relation to its packaging. Bulk density is generally affected by the particle size and density of the flour [20] Karuna, D., D. Noel and K. Dilip, 1996. Food is very indispensable in determining the packaging requirement, material handling and application in wet processing of food industry [21].The bulk density of the control and sample was found to be $1.02,0.72,0.71$, and 0.71 respectively. In comparison, sample 90:10 and 70:30 was found to be similar (0.71), whereas in sample control\&50:50 was 1.02 and 0.72 . Bulk density indicates that the volume of samples during packaging will not decrease excessively during storage and distribution [22].

Foam stability and foam capacity are interrelated in its characteristics. The foam capacity and foam stability of the control and multi cereal composite mix $(50: 50,70: 30,90: 10)$ was found to be $60,98.03,92.78$, 94.07and 5.23,11.20,5.723,7.77 respectively. The foam capacity and foam stability of sample 50:50 was found to be higher when compared with other samples. Researchers explained that protein content is higher in sprouted samples [14 \& 23]. These increases have been attributed to dry matter loss particularly carbohydrates through respiration causing an apparent increase in other nutrients such as protein. Foam capacity and Foam stability is influenced by protein concentration. Foam obtained with higher concentration of proteins is denser and more stable increase in thickness of interfacial films. It has been studied that foaming property is vital for the textural characteristics (porosity) of the product.

\subsection{Amino acid composition of multi cereal composite mix}

The protein in pasta was considered incomplete because it was thought to lack one or two of the essential amino acids, the protein in pasta are low to medium depending on what type of flour. Most pasta is made from durum wheat and this contains both protein and gluten. Protein quality is a functional of essential amino acid composition and it's the ratios of amino acid to each other. Hence the study of the amino acid patterns of multi cereal composite mix and their protein concentrate was of interest. The amino acid composition of control and multi cereal composite mix is given in table 2. The total essential amino acid in control and multi cereal composite mix was found to be 1.03 and 3.84 which was par with [25] FAO/WHO/UNU 2007. Cereals high in Methionine was one of the most abundant of the essential amino acid in the cereals and was present at about 0.51 in multi cereal composite mix when compared to control $(0.31)$. This result is in agreement with previous work done by Laignelet and others 1976; Molina and others 1982. Several studies have reported that germination increased the protein concentration and bioavailability of amino acid of plant based food products, particularly cereals and legumes $[26,27,28,29 \& 30]$

\subsection{Morphological properties and particle size distribution of maida and multi cereal composite mix}

The scanning electron micrographs in Figure 4 show the presence of starch granules varying in size and shape from small to large and oval to elliptical respectively. The surface of the most granules was rather smooth. Starch granules seem to be surrounded by little pieces of other materials like fibres and proteins, giving the appearance of 'raising dust'. The differences in the pictures are the variations in the numbers of individual granules and compound granules. These compound granules were attributed due to the presence of residual protein [31] or due to the drying conditions that produce slight gelatinization on the surface of granules and cause the granules to adhere together to form aggregates [32]. It seems the contribution of residual protein is more than that of gelatinization in the formation the starch flour reconstitutes.

\subsection{Moisture content of pasta}

The initial and final moisture content of the pasta was given in table 3. The initial moisture content of the control and multi cereal pasta $(50 \%, 70 \%$ and $90 \%)$ was found to be $14 \%$ and $21 \%, 18 \%, 19 \%$ and the final moisture content of pasta was found to be $5 \%, 4 \%, 5 \%$ and $5 \%$. According to Temmerman et.,al 2006, Drying pasta in manufactories is realized by using moistened hot air with temperatures ranging between $40.0^{\circ} \mathrm{C}$ and $105.0^{\circ} \mathrm{C}$ and relative humidity varying between $40 \%$ and $95 \%$ which is necessary to reduce the microbiological risk [33]. The maximum moisture content of pasta is $14.3 \%$ (dry basis).

\subsection{Colour}

Colour is an important quality parameter of pasta. It results from the desirable yellow component and the undesirable brown component. The $\mathrm{L}^{*}$ is the measure of the brightness (lightness) from black (0) to white (100).The $a^{*}$ is the function of the red-green difference. Positive $a^{*}$ indicates redness, negative $a^{*}$ indicates greenness. The $b^{*}$ is the function of the green blue difference. Positive $b^{*}$ indicates yellowness, negative $b^{*}$ indicates blueness. The units within the $\mathrm{L}^{*}, \mathrm{a}^{*}, \mathrm{~b}^{*}$ system give equal perception of the colour difference to a human observer. The $L^{*}, a^{*}, b^{*}$ values of the pasta samples with different supplements are presented in Table 4. 
L* control and multi cereal pasta $(50 \%, 70 \%$ and $90 \%)$ was found to be $64,43,37$ and 36 . This difference was associated with the use of multi cereal flour. Higher level of substitution made the product look pale.

\subsection{Cooking quality}

Generally, a cooked pasta samples will weigh three times its precooked weight. A low cooked weight indicated a higher volume of gruel. A high cooked weight indicates a high swelling ability of starch. Significant relation between the degree of swelling and cooked weight [34]. Cooking quality results are tabulated in table5 and fig 5 . The optimum cooking time increased by the addition of $50 \%, 70 \%$ and $90 \%$ multi cereal mix. There was a positive increase in the volume of gruel with as there was more and more multi addition of cereal composite mix to. There was an increase in losses of solids in gruel as well it was found that control sample gave $5.02 \%$ of solids losses, whereas samples with $90 \%$ substitution gave $9.11 \%$ of solid losses.

\subsection{Sensory evaluation of pasta}

Sensory evaluation of pasta samples was carried out by trained and untrained panel using hedonic scale of 1-9 rating starting from dislike extremely to like extremely. The mean scores of sensory evaluation showed that all the extruded products prepared from the multi cereal composite mix in the ratio of 50:50 were within the acceptable range. While the extruded product prepared from the multi cereal composite mix sample had significantly better appearance (7.5), colour (7.35), flavour (7.3), texture (7.6), taste (7.1), mouth feel (7.1), and overall acceptability (7.6). When the extruded samples were compared with the control (100\% maida), the scores revealed that the overall acceptability of the multi cereal composite mix and Maida mixed to the level of 50:50 respectively produced a better acceptable product with great sensory scores. When compared to control the overall acceptability of multigrain, pasta had the highest significant increase in the sensory scores.

\subsection{Nutrient content of the pasta}

The nutrient content of control and multi cereal pasta mix 50:50 was found to be $5.2 \mathrm{~g} \& 11.7 \mathrm{~g}$ of protein $0.01 \mathrm{~g} \& 0.76 \mathrm{~g}$ of fat $68.3 \mathrm{~g} \& 72.3 \mathrm{~g}$ of carbohydrate, $293 \mathrm{Kcal} \& 333 \mathrm{Kcal}$ of calories $0.4 \& 0.7 \mathrm{~g}$ ash, $1.5 \mathrm{~g}$ of fiber and $1.5 \& 2.5$ of iron respectively. From the table 6 , it was found that the nutritional profile of the multi cereal pasta was appreciably higher in all the nutrients. Fiber content is nil in the control sample where as the product consisted of $1.5 \mathrm{~g}$ of fiber. Cereal grains consist of dietary fiber which is associated to reduce the risk of chronic disease [35]. There is an increase in the iron content of multi cereal pasta since it contains finger millet, jowar, bajra and whole wheat which are good sources of iron. Calorific value in the multi cereal pasta is more when compared to control; this is due to increase in carbohydrate, protein and fat content. The whole grains are the rich sources of carbohydrate, protein, fat, vitamins, minerals and fiber [36]. Therefore, multi cereal pasta is highly nutritious when compared to the control.

Table 1 Physical properties of multicereal composite mix

\begin{tabular}{|l|l|l|l|l|l|}
\hline Samples & $\begin{array}{l}\text { Swelling } \\
\text { power } \mathbf{( g / g )}\end{array}$ & $\begin{array}{l}\text { Water } \\
\text { holding } \\
\text { capacity (\%) }\end{array}$ & $\begin{array}{l}\text { Bulk } \\
\text { density }\left(\mathbf{g} / \mathbf{c m}^{\mathbf{3}}\right)\end{array}$ & $\begin{array}{l}\text { Foam } \\
\text { Capacity }\end{array}$ & $\begin{array}{l}\text { Foam } \\
\text { Stability }\end{array}$ \\
\hline Control & $3.46 \pm .057^{\mathrm{a}}$ & $8.73 \pm .346^{\mathrm{a}}$ & $1.02 \pm .034^{\mathrm{a}}$ & $95.96 \pm .444^{\mathrm{a}}$ & $5.23 \pm .635^{\mathrm{a}}$ \\
\hline $\mathbf{5 0 : 5 0}$ & $3.28 \pm .034^{\mathrm{b}}$ & $1.78 \pm .56^{\mathrm{a}}$ & $0.72 \pm .012^{\mathrm{b}}$ & $98.03 \pm .115^{\mathrm{b}}$ & $11.20 \pm .167^{\mathrm{b}}$ \\
\hline $\mathbf{7 0 : 3 0}$ & $3.36 \pm .017^{\mathrm{b}}$ & $1.18 \pm .69^{\mathrm{b}}$ & $0.71 \pm .10^{\mathrm{b}}$ & $92.78 \pm .776^{\mathrm{c}}$ & $5.72 \pm .063^{\mathrm{c}}$ \\
\hline $\mathbf{9 0 : 1 0}$ & $3.13 \pm .057^{\mathrm{c}}$ & $1.13 \pm .57^{\mathrm{c}}$ & $0.71 \pm .001^{\mathrm{b}}$ & $94.0733 \pm .73901^{\mathrm{d}}$ & $7.77 \pm .103^{\mathrm{d}}$ \\
\hline
\end{tabular}

All values are means of triplicate determinations \pm standard deviation (SD)

Column followed by different letters are significantly different $(\mathrm{p}<0.05)$

Table 2 Amino acid composition of multicereal composite mix (g/100g of sample)

\begin{tabular}{|c|c|c|c|c|}
\hline Amino Acid Profile & Control & $\begin{array}{c}\text { Multicereal } \\
\text { composite mix } \\
\text { g/100g }\end{array}$ & $\begin{array}{l}\text { Mean increase } \\
\text { and decrease }\end{array}$ & $\begin{array}{l}\text { g/kg/d } \\
\text { FAO/WHO/ } \\
\text { UNU } 2007\end{array}$ \\
\hline \multicolumn{5}{|c|}{ Essential Amino Acids } \\
\hline Arginine & 0.01 & 0.40 & 0.39 & -- \\
\hline Histidine & 0.08 & 0.46 & 0.38 & 0.14 \\
\hline Isoleucine & 0.09 & 0.11 & 0.02 & 0.19 \\
\hline Leucine & 0.14 & 0.13 & -0.01 & 0.42 \\
\hline Lysine & 0.14 & 0.35 & 0.21 & 0.38 \\
\hline Methionine & 0.30 & 0.51 & 0.21 & 0.15 \\
\hline Phenylalanine & 0.19 & 0.74 & 0.55 & 0.25 \\
\hline Threonine & 0.00 & 0.79 & 0.79 & 0.02 \\
\hline Tryphtophan & 0.00 & 0.22 & 0.22 & 0.05 \\
\hline Valine & 0.08 & 0.13 & 0.05 & 0.24 \\
\hline Total & 1.03 & 3.84 & 2.82 & 1.84 \\
\hline
\end{tabular}


Table 3 initial and final moisture content of pasta

\begin{tabular}{|l|c|c|}
\hline Parameter & Initial & Final \\
\hline Control & 14 & 5 \\
\hline $50: 50$ & 21 & 4 \\
\hline $70: 30$ & 18 & 5 \\
\hline $90: 10$ & 19 & 5 \\
\hline
\end{tabular}

Table 4 colour value of pasta

\begin{tabular}{|c|c|c|c|}
\hline Parameters & $\mathrm{L}^{*}$ & $\mathrm{a}^{*}$ & $\mathrm{~b}^{*}$ \\
\hline Control & $64 \pm 0.57^{a}$ & $-.98 \pm .005^{\mathrm{a}}$ & $10.1 \pm .005^{a}$ \\
\hline $50: 50$ & $43 \pm 0.57^{b}$ & $5.6 \pm .057^{b}$ & $16.4 \pm .005^{b}$ \\
\hline $70: 30$ & $37 \pm 0.57^{c}$ & $4.88 \pm .057^{c}$ & $15.0 \pm .000^{c}$ \\
\hline $90: 10$ & $36 \pm 0.57^{d}$ & $6.05 \pm .034^{d}$ & $16.4 \pm .005^{d}$ \\
\hline
\end{tabular}

All values are means of triplicate determinations \pm standard deviation (SD)

Column followed by different letters are significantly different $(\mathrm{p}<0.05)$

Table 5 Cooking Quality of Pasta

\begin{tabular}{|l|c|c|}
\hline $\begin{array}{l}\text { Pasta } \\
\text { samples }\end{array}$ & Cooked weight (g/25 g) & $\begin{array}{l}\text { Cooking loss } \\
(\%)\end{array}$ \\
\hline Control & $70 \pm .577^{\mathrm{a}}$ & $5.02 \pm .005^{\mathrm{a}}$ \\
\hline $50 \%$ & $65 \pm .577^{\mathrm{b}}$ & $6.13 \pm .005^{\mathrm{b}}$ \\
\hline $70 \%$ & $60 \pm .577^{\mathrm{c}}$ & $8.05 \pm .005^{\mathrm{c}}$ \\
\hline $90 \%$ & $55 \pm .577^{\mathrm{d}}$ & $9.11 \pm .005^{\mathrm{d}}$ \\
\hline
\end{tabular}

All values are means of triplicate determinations \pm standard deviation (SD) Column followed by different letters are significantly different $(\mathrm{p}<0.05)$

Table 6 Nutrient content of the pasta

\begin{tabular}{|l|c|c|c|}
\hline \multirow{2}{*}{$\begin{array}{l}\text { Nutrient } \\
\text { Content }\end{array}$} & Control & Multicereal pasta & t value \\
\cline { 2 - 4 } & Mean \pm SD & Mean \pm SD & $\mathbf{0 . 0 0 *}$ \\
\hline Protein(g) & $5.2 \pm .020$ & $11.7 \pm .251$ & $\mathbf{0 . 0 0 *}$ \\
\hline Fat $(\mathrm{g})$ & $0.01 \pm .003$ & $.76 \pm .057$ & $\mathbf{0 . 0 0}$ \\
\hline Carbohydrate $(\mathrm{g})$ & $68.3 \pm .575$ & $72.3 \pm .57$ & $\mathbf{0 . 0 0 *}$ \\
\hline Fiber(g) & - & 1.5 & $\mathbf{0 . 0 0 *}$ \\
\hline Ash(\%) & $0.46 \pm .057$ & $0.70 \pm .20$ & $\mathbf{0 . 0 0 *}$ \\
\hline Iron(mg) & $1.5 \pm .00$ & $2.5 \pm .00$ & $\mathbf{0 . 0 0 *}$ \\
\hline Calorific value (k.cal) & $293 \pm .57$ & $333 \pm .37$ & $\mathbf{0 . 0 0 *}$ \\
\hline
\end{tabular}

All values are means of triplicate determinations \pm standard deviation (SD)

*Significantly different $(\mathrm{p}<0.05)$

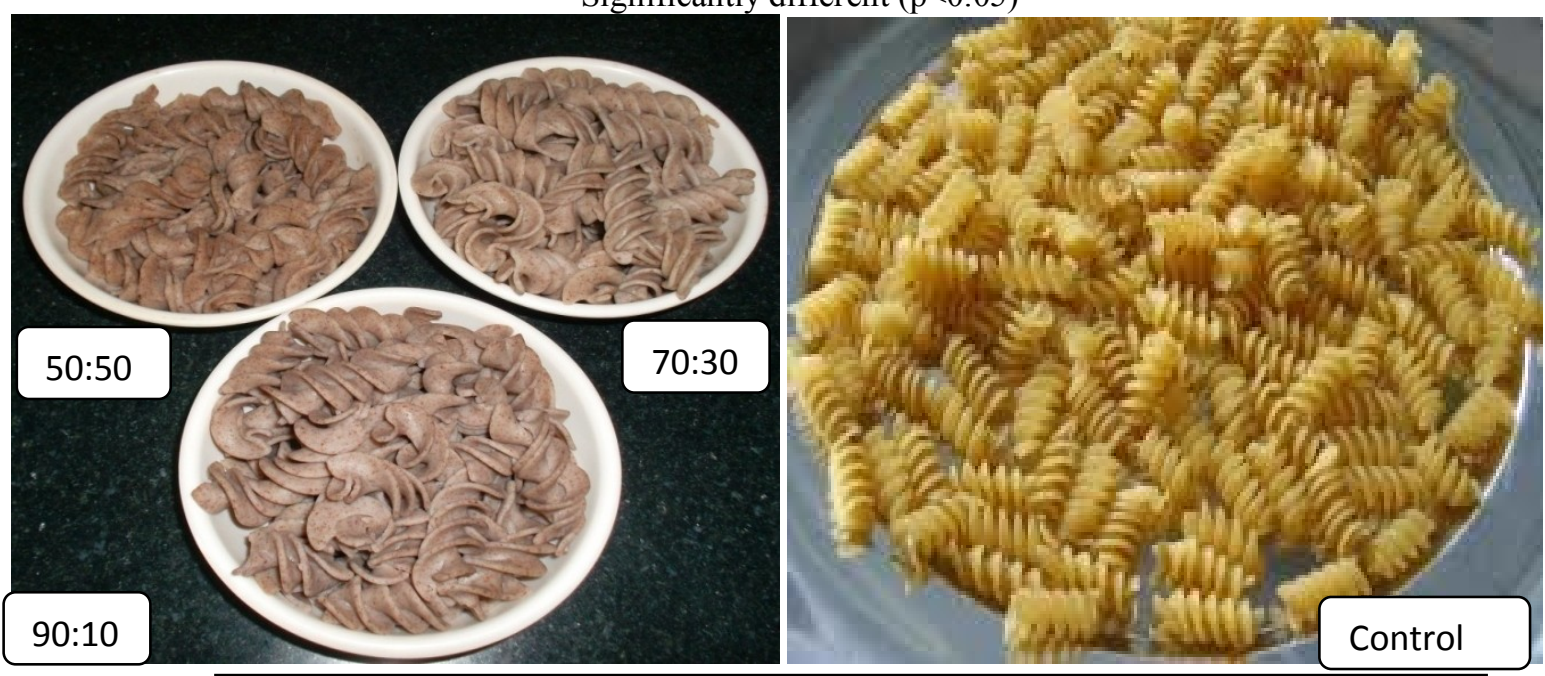

Fig 1 Formulated Multicereal Pasta 


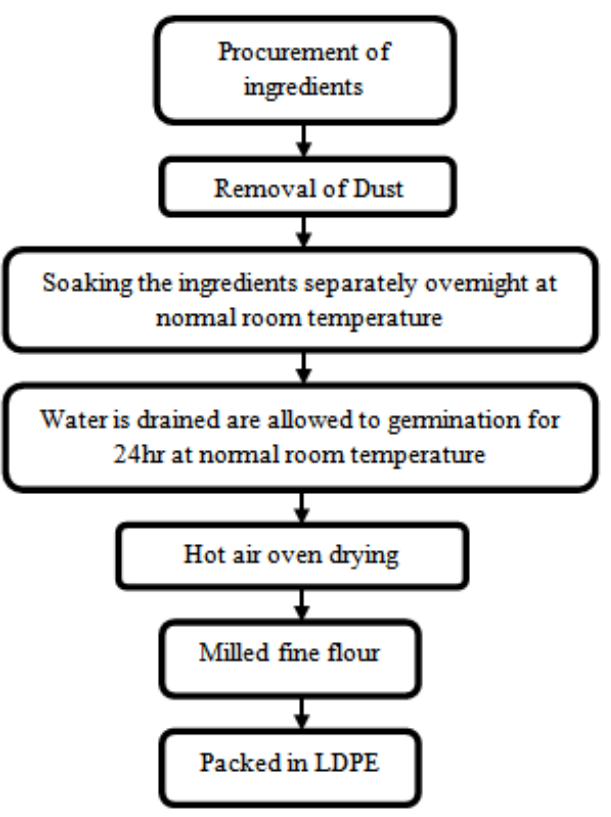

Fig 2 Process involved in the preparation of multicereal composite mix

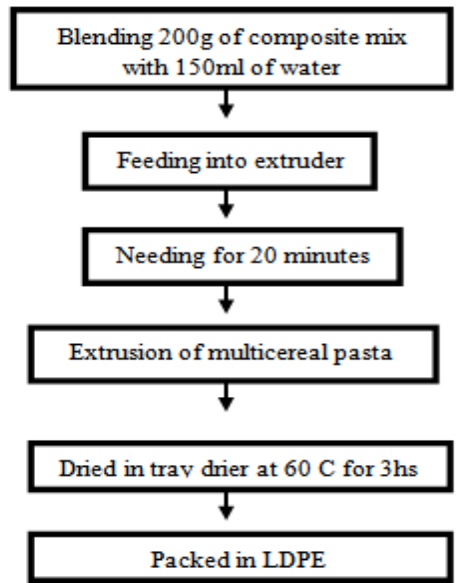

Fig 3 Process involved in the preparation of multicereal composite mix

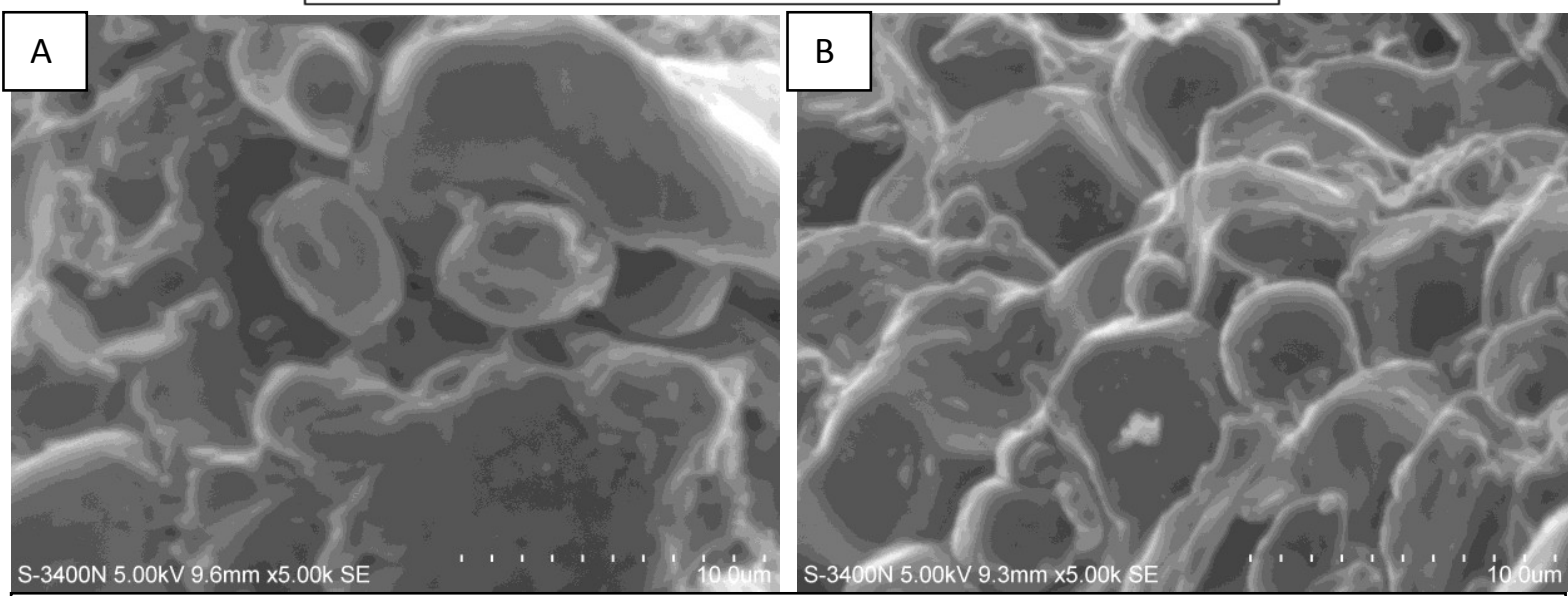

Fig 4 Morphology of (A) Maida and (B) multicereal composite mix as measured by scanning electron microscopy at $1000 \mathrm{X}$ 


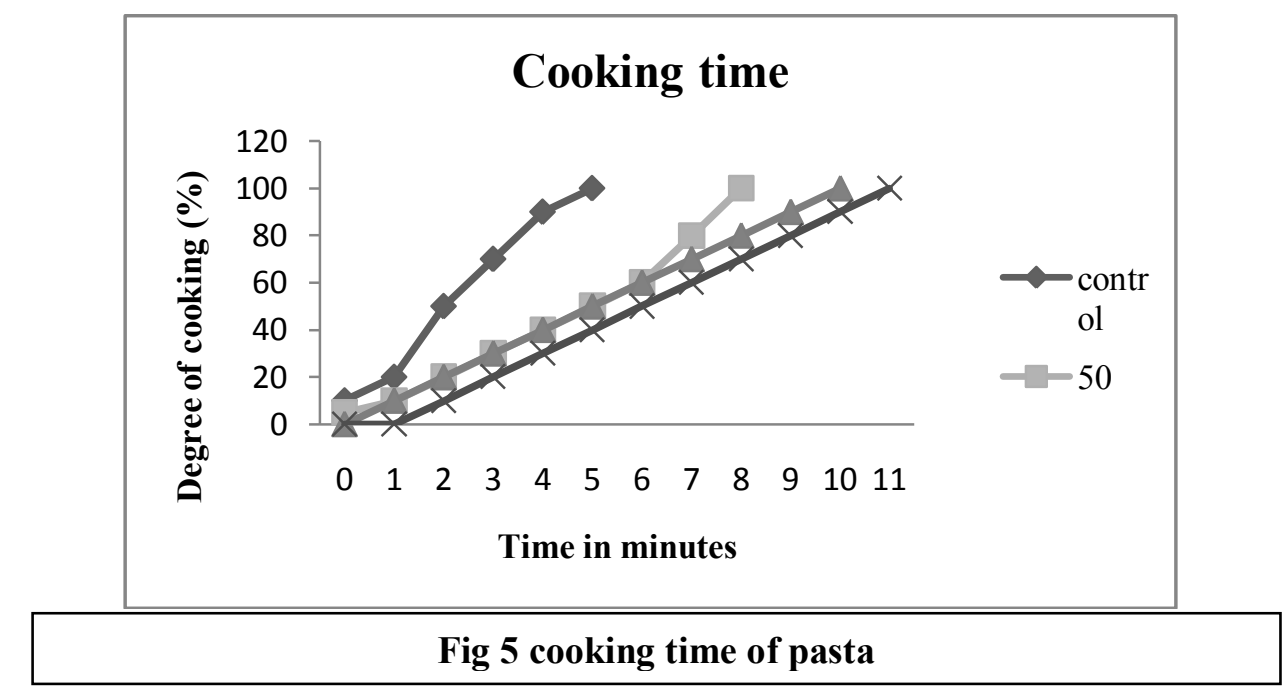

\section{Conclusion}

Pasta has a universal appeal and good carrier for supplying nutrition for such a section of people who are health conscious. The addition of increasing levels of fiber in a long way improves the health status of vast majority of health conscious population. The results illustrate the potentiality and functionality of cereals to enrich durum wheat pasta for the production of dietetic pastas that had high dietary fiber and protein content with nutritional benefits. These cereals can be added up to 50 percent level without adversely affecting the physicochemical, cooking and sensory quality of pasta. These types of enriched pasta products can go a long way in supplying the required quantities of dietary fiber and protein to various segments of our populations and will also result in profitable utilization of byproducts of milling industry.

\section{REFERENCES}

[1] Kill, R.C..Introduction in Pasta and Semolina Technology, Blackwell Sciences Ltd., London, U.K. p. (2001)11-42

[2] Tina, F. and Prabhasankar, P. 2010. Role of ingredients inpasta product quality: A review on recent developments. Critical Reviews in food science and nutrition 50 (8).2010:787-798.

[3] Douglass, J.S. and Matthews, R.H.. Nutrient content of pasta products. Cereal Foods World. 27(3) 1982 558-561.

[4] Prabhasankar P, Ganesan P \& Bhaskar N. Influence of Indian brown seaweed (Sargassum marginatum) as an ingredient on quality, biofunctional, and microstructure characteristics of pasta. Food Science and Technology International 15(5) 2009:471-479.

[5] Brennan CS. Dietary fibre, glycaemic response, and diabetes. Molecular Nutrition \& Food Research 49(6) 2005 :560-570.

[6] Oberg, P. Co-extrusion: Recent developments using cooking Extruder. Cereal Foods World 32(2). $2000: 816-819$.

[7] Leach HW, McCowen LD \& Schoch TJ. Structure of the starch granule. I. Swelling and solubility patterns of various starches. Cereal Chem 36(6) $1956: 534-544$.

[8] Beuchat LR. Functional and electrophoretic characteristics of succinylated peanut flour protein. Journal of Agricultural and Food Chemistry 25(2) $1977: 258-261$.

[9] Okaka JC \& Potter NN. Physicochemical and functional properties of cowpea powders processed to reduce beany flavor. Journal of Food Science 44(4) $1979: 1235-1240$.

[10] Narayana and NarasingaRao. Implications of antinutritional components in soybean foods. CRC Reviews Food Science and Nutrion 34(3) 1985: 31-67.

[11] AOAC.. Official Methods of Analysis. Association of Official Analytical Chemists. Washington, DC, 200016th Edition.

[12] AACC.. Approved Methods of the AACC, 200511th Ed., American Association of Cereal Chemists, St. Paul, MN.

[13] Bhat, G.T.C.M. \& Sharma, K.. Organoleptic evaluation of nutritious dhal vadas. Journal of Agricultural Research, 26 (2) 1989: 334338 .

[14] Mbithi-Mwikya S, Van Camp J, Yiru Y \& Huyghebaert A.. Nutrient and Antinutrient Changes in Finger Millet (Eleusinecoracan) During Sprouting. LWT-Food Science and Technology 33(1) 2000:9-14.

[15] Dendy, D.A.V., Riley, K.W., Gupta, S., Seetharam, A. \&Mushonga., J.N. Opportunities for non-traditional uses of the minor millets Journal of Nutrition. 33(4) 1993: 259-270.

[16] Laignelet B, Feillet P, Nicolas D, Kadane V. 1976. Potential use of soy proteins in the pasta industry. Lebensm-Wiss U-Technol 9:24-8.

[17] Adebowale KO \& Lawal OS.. Comparative study of the functional properties of bambarra groundnut (Voandzeia subterranean), jack bean (Canavalia ensiformis) and mucuna bean (Mucuna pruriens) flours. Food Research International 37(4) 2004:355-365.

[18] Houssou P \& Ayernor GS. Appropriate processing and food functional properties of maize flour. African Journal of Science and Technology 3(1) 2004.

[19] Fellows,P.J . Food processing technology: Principles and Practice. Second Edition pp:297, 2000.CRC Press , Boca Raton, Boston Washington DC.

[20] Karuna, D., Kulkarni, D. N. and Ingle, U. M. Fractionation, solubility and functional properties of cowpea (Vigna unguiculata) proteins as affected by $\mathrm{pH}$ and/or salt concentration. Journal of Food Chemistry 82(2) 1996.: 207-212.

[21] Karuna, D., Noel, G., \& Dilip, K.. Production and use of raw potato flour in Mauritanian traditional foods. Food \& Nutritional bulletin 17 (2) 1996: 12-14

[22] Ogunlakin GO, Oke MO, Babarinde GO \& Olatunbosun DG. Effect of Drying Methods on Proximate Composition and Physicochemical Properties of Cocoyam Flour. American Journal of food technology 7(4):245-250. 
[23] Opoku AR, Ohenhen SO \& Ejiofor N. 1981. Nutrient composition of millet (Pennisetum typhoides) grains and malt. Journal of Agricultural and Food Chemistry 29(6) 1981:1247-1248.

[24] Staudt, E. and Ziegler. (1973). Flour Chemistry $1{ }^{\text {st }}$ ED. Bhuler Brothers Ltd., Engineering Works 9240 Uzwil, Switerzerland.

[25] Joint FAO/WHO/UNU . Expert Consultation on Protein and Amino Acid Requirements in Human Nutrition. WHO Technical Report Series 2007. No.935.

[26] Camacho L, Sierra C, Campos R, Guzm $\tilde{A}_{i n}$ E \& Marcus D. [Nutritional changes caused by the germination of legumes commonly eaten in Chile]. Arch Latinoam Nutr 42(3) 1992:283-290.

[27] Egli I, Davidsson L, Juillerat MA, Barclay D \& Hurrell RF. The Influence of Soaking and Germination on the Phytase Activity and Phytic Acid Content of Grains and Seeds Potentially Useful for Complementary Feedin. Journal of Food Science 67(9) 2002:34843488 .

[28] Helland MH, Wicklund T \& Narvhus JA. Effect of germination time on alpha-amylase production and viscosity of maize porridge. Food Research International 35(2) 2002:315-321.

[29] Egli I, Davidsson L, Zeder C, Walczyk T \& Hurrell R. Dephytinization of a Complementary Food Based on Wheat and Soy Increases Zinc, but Not Copper, Apparent Absorption in Adults. The Journal of Nutrition 134(5) 2004:1077-1080.

[30] Gernah DI, Ariahu CC \& Ingbian EK. Effects of malting and lactic fermentation on some chemical and functional properties of maize (Zea mays). American Journal of food technology 6(5):404-412.

[31] Molina MR, Gudiel H, Baten MA \& Bressani R. 1982. Production of high-protein quality pasta products using a semolina/corn/soy flour mixture. III. Effect of cooking on the protein nutritive value of pasta. Cereal Chemistry 59.

[32] Newman AW, Vitez IM, Kiesnowski C \& Mueller RL. Starches and starch derivatives. Encyclopedia of pharmaceutical technology, Swarbrick J, Boylan JC (eds.). Marcel Dekker, Inc., 1996 New York:223-248.

[33] Ocheme OB, Alash AM \& Zakari UM. 2008. Effect of Malting And Soybean Supplementation on The Nutrient Quality and Acceptability Of "eko-eda" $\square$ : A MAIZE GRIT PORRIDGE. Food Science and Technology 2:14-19.

[34] Dexter JE, Matsuo RR \& Morgan BC. Spaghetti Stickiness: Some Factors Influencing Stickiness and Relationship to Other Cooking Quality Characteristics. Journal of Food Science 48(5) 1983:1545-1551.

[35] Adom LP, Hectorn KJ, Reynolds H \& Hunninghake DB.. Cholesterol-lowering effects of soluble-fiber cereals as part of a prudent diet for patients with mild to moderate hypercholesterolemia. The American Journal of Clinical Nutrition 52(6) 1990:1020-1026.

[36] Jonnalagadda SS, Harnack L, Liu RH, McKeown N, Seal C, Liu S \& Fahey GC. Putting the whole grain puzzle together: Health benefits associated with whole grain summary of American Society for Nutrition 2010 Satellite Symposium. The Journal of Nutrition 141(5): $1011 S-1022 S$. 